\title{
Chemical Composition, Functional Properties, and Effect of Inulin from Tunisian Agave americana L. Leaves on Textural Qualities of Pectin Gel
}

\author{
Mohamed Ali Bouaziz, Rabaa Rassaoui, and Souhail Besbes \\ Ecole Nationale d'Ingénieurs de Sfax, Laboratoire Analyses Alimentaires, Route de Soukra, 3038 Sfax, Tunisia \\ Correspondence should be addressed to Mohamed Ali Bouaziz; medalibouaziz@yahoo.fr and Souhail Besbes; besbes.s@voila.fr
}

Received 30 May 2013; Accepted 29 October 2013; Published 23 January 2014

Academic Editor: Hamadi Attia

Copyright (C) 2014 Mohamed Ali Bouaziz et al. This is an open access article distributed under the Creative Commons Attribution License, which permits unrestricted use, distribution, and reproduction in any medium, provided the original work is properly cited.

\begin{abstract}
In this study, the chemical composition and functional properties of Agave americana L. (AA) leaves were determined. The Agave leaves powder had a high amount of total dietary fiber (38.40\%), total sugars (45.83\%), and protein (35.33\%), with a relatively low content in ash (5.94\%) and lipid (2.03\%). The Agave leaves were exhibited with potential food application. The Agave inulin showed a significant difference compared with the commercial inulin as for aw (0.275 against 0.282$)$, pH (5.53 against 5.98), ash (2.89\% against $1.19 \%)$, protein (3.46\% against $1.58 \%)$, water holding capacity (2.42\% against $1.59 \%)$, solubility ( $73 \mathrm{~g} / \mathrm{L}$ against $113 \mathrm{~g} / \mathrm{L})$, and emulsion capacity (14.48\% against 21.42\%), respectively. The textural properties of Agave inulin-pectin mixed gels were examined using instrumental Texture Profile Analysis (TPA). Firmness of the prepared Agave inulin-pectin mixed gels was lower than the pectin gel ( $0.3554 \mathrm{~N}$ against $5.7238 \mathrm{~N}$, resp.). This reduction of firmness showed a synergetic effect between pectin and inulin. These results suggested a positive interaction between Agave inulin and pectin to decrease the firmness of mixed gels and open a good alternative to obtain value added products from this resource.
\end{abstract}

\section{Introduction}

Agave is usually thrived in semiarid regions such as Mexico, Australia, and Africa. Commonly grown species include Agave americana L., Agave attenuata, and Agave tequilana. Different from other Agave species, AA L. has a large asparagus-like flower stalk, but no piñas. Because of no piñas (a reservoir of fructans), the $\mathrm{AA}$ is commercially less valuable for the production of alcoholic beverages, compared to other Agave species such as Agave tequilana and Agave attenuate, although its leaves can be used for pulque (a beer-like drink) production. Agave is the biggest genus that identifies a group of desert plants belonging to the monocotyledonous family called Agaveceae [1]. This genus is characterized by spiny leaves yielding various types of fibers and composed of wild plants that do not need tender care and are traditionally used as source of fibers. The North American AA plant is a species belonging to such a genus, which is also flourishing in South of Africa as well as the Mediterranean area [2]. Various species of Agave are used in the traditional medicine either as medicinal plants or as good anti-inflammatory agents $[3,4]$. Uribe and Saldivar [5] confirmed the anticancerogenic and antioxidant properties of the Agave syrup. This plant has been shown to have both antibacterial and antifungal properties [6]. Moreover, the leaf of AA base contains up to $16 \%$ of fructans. Pina and leaf base can be used for the commercial production of fructans and long-chain inulin, which can be used as vaccine adjuvant in the pharmaceutical industry [7]. This Agave plant is native to Mexico and other parts of the Caribbean area $[8,9]$. Plants were taken from there to Europe, Africa, and the Far-East by the Spanish and Portuguese, where they naturalized rapidly, especially in the high arid regions around the shores of the Mediterranean [10].

In Tunisia, the AA is the most abundant variety of Agave [11]. This variety is characterized by the fact that it is a much voluminous plant with long, fleshy, rigid, hard-surfigured, and lanceolate leaves growing directly out from the central stalk to form a dense rosette. Its floral stalk, sometimes 
termed the trunk, can reach 10 to $20 \mathrm{~m}$ of length. Evaluation of AA as a source of fiber was launched recently in Tunisia, where fibers are extracted traditionally and used for making twines and ropes [12]. The AA was much used by Tunisians for its fibers when fibers extracted by simple immersion in seawater were used to make ropes and twines for agricultural, marine purposes and known for its wealth of structural insoluble polysaccharides [13] and soluble polysaccharides [14]. Thus, it would be wise to valorise any noble fractions of AA.

On the other hand, inulin is the second polysaccharide reserve most abundant after starch. It is the main reserve carbohydrate [15-17]. It can be found, for instance, in onions ( $1-5 \%$ on a fresh weight basis), garlic ( $4-12 \%)$, banana $(0.2 \%)$, and chicory roots (15-20\%). Indeed, by its chemical structure, inulin is not hydrolysed or absorbed in the small intestine, and then it is considered a soluble fiber that can be incorporated into various food products. Its low sweetness and its properties similar to sucrose allow it to replace sugar in some formulations. inulin stimulates the growth of bifidobacteria, which is believed to have health-promoting functions. Many other health enhancing aspects of inulin concern diabetes, lipid metabolism, cancer prevention, and antiulcer activity $[18,19]$.

The technological use of inulin is based on its properties as a sugar replacer (especially in combination with high intensity sweeteners), as a fat replacer and texture modifier. For fat replacement in low-fat dairy products inulin seems particularly suitable as it may contribute to an improved mouthfeel. Also, inulin was used to improve rheological characteristics and nutritional properties of food and to be classified among functional foods [20].

Inulin gel formation is different from that obtained with hydrocolloids. inulin forms particle gels, whereas the increase of viscosity through most hydrocolloids is obtained by bonds between chains [21]. Rheological properties of inulin are quite well documented in the literature [22-24]. Interactions of inulin with some carbohydrates such as maize starch, maltodextrins, or pectin have also been analysed [24-26].

Gelling properties of pectin may be affected by many factors. Increased degree of methoxylation (DM) resulted in higher setting temperature and so more rapid gel formation for high methoxyl pectin (PHM) [27]. C. Rolin and J. de vries [28] reported that calcium addition also influences gel formation behaviour of PHM [28]. Moreover, gelling temperature increases in the presence of $\mathrm{Ca}^{2+}$. Calcium content influences also the rheological behaviour of low methoxyl (LM) pectin gels by increasing $\mathrm{G}^{\prime}$ (elastic modulus), but at $\mathrm{Ca}^{2+}$ levels that are too high, syneresis may occur. Contrarily to PHM, the gel temperature increases with decreasing DM. In addition, LM pectin with a blockwise distribution of free carboxyl groups is very sensitive to calcium [29].

Interactions between mixed biopolymer systems of which pectin is one component have been largely studied, such as pectin/alginate [30], pectin/starch [31], and pectin/gelatine [32] mixtures. However, few studies exist on the behaviour of mixed inulin-pectin gels. Pectin mixtures are widely used in food applications to obtain products with better properties.

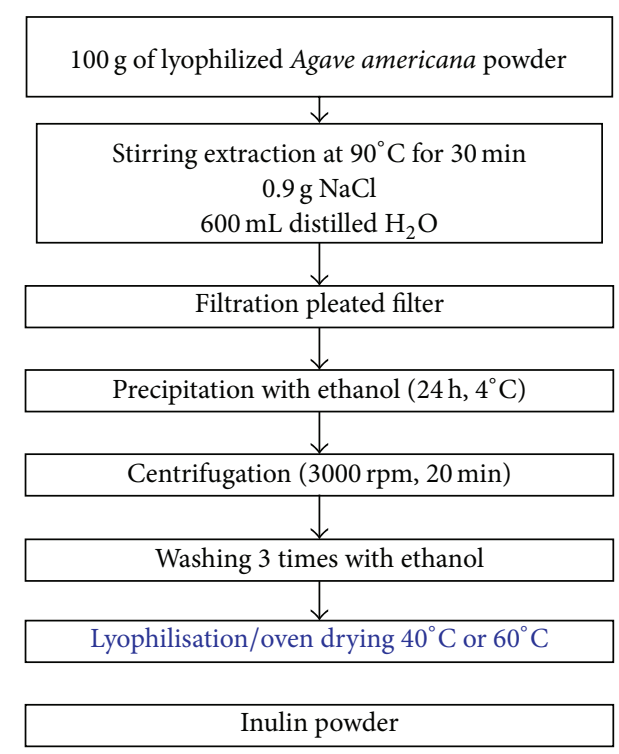

FIGURE 1: Extraction diagram of inulin from Agave americana L.

The aim of the present work is to characterize leaves powder and inulin from the AA and next to study the synergistic effect of inulin on pectin gel for food preparations.

\section{Materials and Methods}

2.1. Origin of Materials. AA plants cultivated organically were collected at the same time from the same cultivation zone (M'saken, Sousse, Tunisia). Leaves were obtained from plants at the same stage of maturation. In this work, the basal leaves of AA were used. $5 \mathrm{~kg}$ of leaves is cut into large pieces and stored at $-20^{\circ} \mathrm{C}$ until use for the different analyses.

The pectin (high methyl pectin (PHM), medium rapid set) was supplied by Zina company, Sfax, Tunisia.

2.2. Preparation of the Sampling. At the first step, AA leaves were washed with water and the chlorophyll cuticle is removed. Then, the leaves are cut into small pieces and milled using a laboratory mixer. After that, the resulting biomass was lyophilized and stored at $4^{\circ} \mathrm{C}$ until the analysis.

2.3. Extraction Process. The inulin from AA leaves was extracted by mixing $600 \mathrm{~mL}$ of distilled water per $100 \mathrm{~g}$ of sample and the mixture was blended in a mechanical device made of stainless steel with $0.9 \mathrm{~g}$ of salt/L and then stirred at $90^{\circ} \mathrm{C}$ for $30 \mathrm{~min}$ (Figure 1). The suspension was filtered on canvas and then the supernatant was filtered under vacuum with Whatman paper. The filtrate was precipitated with ethanol (90\%) overnight at $4^{\circ} \mathrm{C}$ and centrifuged at $3000 \mathrm{rpm}$ for 20 minutes. The obtained pellet was subjected to three washes with ethanol, lyophilized or oven dryed at $40^{\circ} \mathrm{C} / 60^{\circ} \mathrm{C}$, and stored in desiccators until they were analysed $[33,34]$.

2.4. Chemical Composition. All analytical determinations were performed at least in triplicate. Values of different 
parameters were expressed as the mean \pm standard deviation $(X \pm \mathrm{SD})$.

Dry matter was determined according to the Association of Official Analytical Chemists [35].

Nitrogen content of samples was determined by Kjeldahl method, following the method of the AOAC (1995) [35]. Protein content of each sample was calculated by multiplying the total nitrogen content by a factor of 6.25 [36].

Ash content was determined after incineration at $550^{\circ} \mathrm{C}$, during 8 hours, using a muffle furnace (NABER, Germany). It was expressed as percent of dry weight [35].

Fat content was determined by continuous extraction with a Soxhlet on samples previously dried and ground, according to the method of the AOAC. The solvent used for this analysis is hexane [35].

Fiber was determined by the adopted method described by Prosky et al. (1988) [37]. This is an enzyme-gravimetric method officially classified by AOAC (1995) [35]. The Agave leaves were crushed by an electric grinder for fine particles. Then, the sampling is gelatinized with a thermostable $\alpha$ amylase (A-3306) and next treated with a protease (P3910) and amyloglucosidase (A-3042) (11500 units/mL) to hydrolyze proteins and starch.

After enzymatic hydrolysis, the residues were recovered by centrifugation and washed with distilled water (twice), alcohol 95\% (twice), and acetone (once). Finally, residues are dried and weighed. Corrections are made during the determination of protein and ash. Insoluble fiber (IF) content is calculated using the following formula:

$$
\% \mathrm{IF}=(\text { Residue }-(\text { Protein }+ \text { Ash })) \times 100 .
$$

After enzymatic attack, 4 volumes of $95 \%$ ethanol were added to the supernatant to precipitate inulin. The precipitate, collected by centrifugation, was washed successively with $75 \%$ ethanol, $95 \%$ ethanol, and acetone. The dried residue was weighed. Corrections are made during the determination of protein and ash. Soluble fiber (SF) content is determined from the following formula:

$$
\% \mathrm{SF}=((\text { Residue })-(\text { Protein }+ \text { Ashes })) \times 100 .
$$

The total dietary fiber (TF) is determined as the sum of insoluble and soluble fiber:

$$
\% \mathrm{TF}=\% \mathrm{IF}+\% \mathrm{SF}
$$

Soluble sugars are firstly extracted with $15 \mathrm{~mL}$ of a solution of $96 \%$ ethanol with stirring at room temperature and then centrifuged at $9418 \mathrm{~g}, 4^{\circ} \mathrm{C}$ for $20 \mathrm{~min}$. Secondly, the resulting residue was washed with $5 \mathrm{~mL}$ of a solution of $80 \%$ ethanol. Then, the supernatants were collected and evaporated to obtain a volume of $1 \mathrm{~mL}$. Finally, it was adjusted to obtain $10 \mathrm{~mL}$ with distilled water [38]. The obtained solution was analyzed by the phenol-sulfuric method [39].

Polysaccharides were determined as follows: the residue obtained from soluble sugars extraction was stored for 24 hours at room temperature to evaporate the ethanol traces. Then, $10 \mathrm{~mL}$ of $\mathrm{HCl}(30 \%)$ was added and the mixture was incubated in a water bath at $60^{\circ} \mathrm{C}$ for 2 hours and then centrifuged at $9418 \mathrm{~g}, 4^{\circ} \mathrm{C}$ for $30 \mathrm{~min}$. The supernatant was filtered through a filter paper and then adjusted to $10 \mathrm{~mL}$ with distilled water. The obtained solution was analyzed by the phenol-sulfuric method [39]. The assay is performed with a mixture $(\mathrm{v} / \mathrm{v})$ of $1 \mathrm{~mL}$ of the solutions obtained with a solution of $5 \%$ phenol. $5 \mathrm{~mL}$ of concentrated sulfuric acid is then added and the mixture was placed in water bath at $25-30^{\circ} \mathrm{C}$ for $20 \mathrm{~min}$. The optical density was measured at a wavelength $\lambda=$ $490 \mathrm{~nm}$ with a spectrophotometer (SHIMADZU mini 1240). The concentration of soluble sugars and polysaccharides is determined against a standard curve made with glucose. Total sugars were the sum of soluble sugars and polysaccharides.

The mineral constituents $(\mathrm{Ca}, \mathrm{Mg}, \mathrm{Na}, \mathrm{K})$ were analyzed separately, using an atomic absorption spectrophotometer (Hitachi Z6100, Japan).

The $\mathrm{pH}$ was measured using a $\mathrm{pH}$-meter (METTLER TOLEDO MP220) at $20^{\circ} \mathrm{C}$.

The levels of soluble solids of raw material, expressed as ${ }^{\circ}$ Brix, were measured using a refractometer (Mod. DR101, Coseta S.A., Barcelona, Spain). Both measurements were taken at $20^{\circ} \mathrm{C}$.

Water activity was measured by a NOVASINA aw Sprint TH-500 Apparatus. The measurement was performed at $25^{\circ} \mathrm{C}$.

\subsection{Determination of Technofunctional Properties}

2.5.1. Particle Size. The measurement of particle size distribution tells us about the size of Agave leaves powder. This particle size was measured using a sieve with a mesh size of $200 \mu \mathrm{m}$ (Model VE 100, Retch, Germany). The fine fraction (particle size $<200 \mu \mathrm{m}$ ) was used for analysis.

\subsubsection{Water Holding Capacity and Oil Holding Capacity} (WHC and OHC). The method of Moure et al. (2001) was used with a slight modification. $1 \mathrm{~g}$ of samples was stirred in $10 \mathrm{~mL}$ of distilled water or corn oil and then centrifuged at $7125 \mathrm{~g}$ for $20 \mathrm{~min}$ (JOUAN CR4 22, USA). The volume of the supernatant was measured. The water-holding capacity was expressed as the number of gram of water held by $1 \mathrm{~g}$ of sample. The oil-holding capacity was expressed as the number of gram of oil held by $1.0 \mathrm{~g}$ of sample [40].

2.5.3. Emulsion Capacity (EC). The emulsion capacity was determined by a model system described by Blecker et al. (1997). Then, sunflower oil was added to $50 \mathrm{~mL}$ of solutions $(7 \% \mathrm{w} / \mathrm{v})$ and emulsified using an Ultraturax T25 (IKa, Staufen, Germany) at $15000 \mathrm{rpm}$ for $10 \mathrm{~min}$. During emulsification, temperature was maintained at $0^{\circ} \mathrm{C}$ by immersing the reaction vessel in ice bath. The sudden increase in electrical resistance showed the phase inversion point; the oil phase becomes continuous, which can be determined by electrical conductivity measurements. Emulsion capacity is expressed in $\mathrm{g}_{\text {oil }} \mathrm{g}^{-1}$ of sample [41].

2.5.4. Swelling Power. A dispersion of $200 \mathrm{mg}$ of dietary soluble fiber in $10 \mathrm{~mL}$ of distilled water was introduced into a graduated cylinder. After 18 hours of standing at room 
temperature, the amount of water retained by the fibers was determined. The swelling is the ratio between the volume of water and the test [42].

2.5.5. Solubility. The solubility of inulin extracted from the Agave leaves and commercial inulin was determined as follows: at $25^{\circ} \mathrm{C}$. inulin was added slowly in $10 \mathrm{~mL}$ of water under stirring until complete dissolution and saturation. The solubility is expressed as the mass of inulin dissolved in one liter of distilled water [43].

2.5.6. Pectin-Inulin Mixed Gel Preparation. High methoxyl pectin (PHM), inulin, and mixed gels were prepared to study the effect of Agave inulin on gelling properties. 15\% to $30 \%$ of inulin extracted from AA was used and dissolved in $50 \mathrm{~mL}$ of distilled water and added with sucrose until a $55^{\circ}$ Brix of soluble solid levels. Subsequently, the PHM (4\%) was added and dissolved by stirring. The $\mathrm{pH}$ was adjusted to 3 using a citric acid solution (10\%). The obtained solution was heated to boiling with stirring until reaching a $65^{\circ} \mathrm{Brix}$ of soluble solids extract. Finally, the preparation was setting into cylindrical containers $(3.5 \mathrm{~cm}$ diameter $\times 3 \mathrm{~cm}$ height $)$. The solutions were cooled to room temperature overnight (Figure 3). Similarly, standard solutions at $4 \%$ of pectin and $20 \%$ of commercial inulin concentrations were prepared with distilled water and compared to mixed gels (the ratio PHM/inulin mixture was $4: 20$ ).

2.5.7. Texture Analysis. Penetration test was performed with a Texture Analyzer (Analysis LLOYD instruments, Fareham, UK) interfaced to a personal computer (Windows-based Software NEXYGEN PLOT). Constant speed penetration tests were performed directly on cylindrical containers $(3 \mathrm{~cm}$ diameter $\times 3.5 \mathrm{~cm}$ height). All instrumental texture analyses were conducted on chilled $\left(25^{\circ} \mathrm{C}\right)$ samples. A cylindrical probe ( $25 \mathrm{~mm}$ of diameter) was introduced for $30 \mathrm{~mm}$ into the samples (the speed $=40 \mathrm{~mm} / \mathrm{min}$ ). The prepared gels were subjected to a test initiation of chewing (Texture Profile Analysis). From the force-versus-time curves, values for the maximum force $(\mathrm{N})$ were calculated as force at a distance of $15 \mathrm{~mm}\left(F_{\max }\right)$ and a detection limit of $0.005 \mathrm{~kg}$ force into two times. Triplicate measures for each gel were performed. Textural parameters considered in the present study were firmness, elasticity, cohesiveness, adhesiveness, and chewiness.

2.6. Statistical Analysis. One-way analysis of variance (ANOVA) was used to determine significant differences $(P<0.05)$ between inulin-PHM gels and PHM or inulin gels. Duncan's test was used to access the differences between gels. Statistical analyses were performed on statistical analysis package STATISTICA (Release 5.0 Stat Soft Inc. Talsa, OK).

\section{Results and Discussion}

3.1. Physicochemical Properties of Powder and Inulin from Agave americana L. Leaves. The extracted powder and inulin from AA leaves were illustrated in Figure 2. The proximate

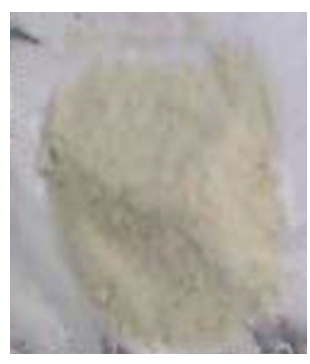

(1)

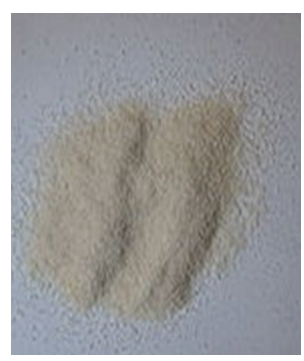

(2)
Figure 2: Agave americana leaves powder (1) and inulin (2).

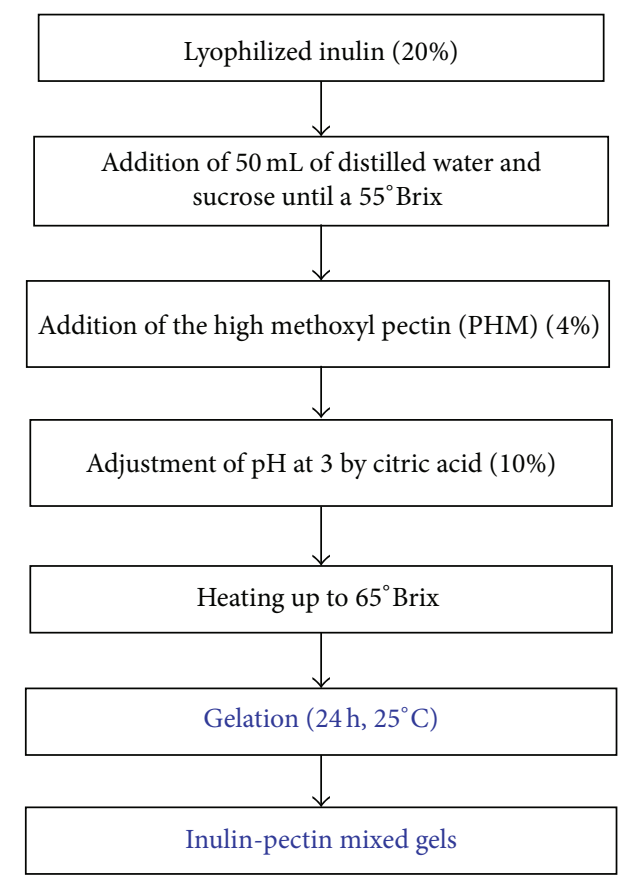

FIGURE 3: Diagram of inulin-pectin gels preparation.

composition of leaves powder from AA plant was presented in Table 1. Results showed a low content of the water $(5.86 \%)$ which facilitates their conservation. But Agave is a succulent plant, and this recalls the rich succulence racket prickly when water content was approximately $92 \%$ [44].

Moreover, the total fiber content was the highest (38.40\%) followed by protein content $(35.33 \%)$ with a relatively low lipid (2.03\%) and Ash (5.94\%) levels.

The sugar fractions of Agave leaves were essentially formed by insoluble and soluble sugars (3.16\% and $42.67 \%$ of total sugars, resp.). Agave leaves contained a high insoluble fiber level which confirms the appearance of the flesh filamentous leaves [45]. However, the soluble fiber fraction was lower compared to insoluble fiber fraction (9.03\% against 29.37\%). The soluble fraction was represented mainly by fructans [14]. The presence of this fraction confirms the choice of using leaves part of the plant for inulin extraction.

Table 1 shows the mineral composition of AA leaves powder. A predominance of potassium $(1.096 \mathrm{mg} / 100 \mathrm{~g}$ of 


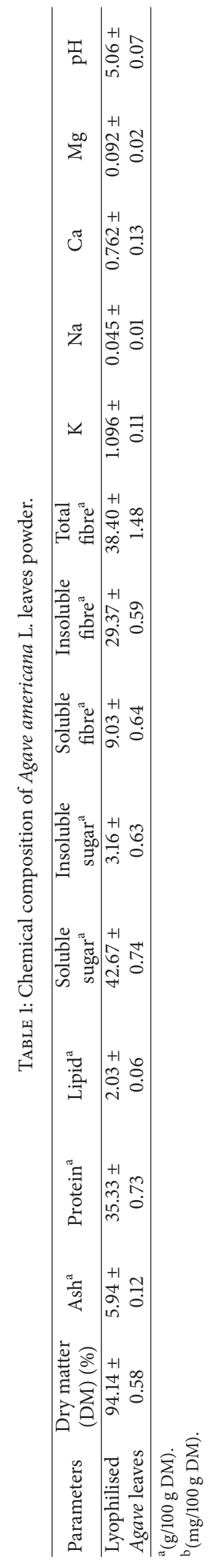


TABle 2: Physicochemical properties of inulin obtained from Agave americana L. and commercial inulin (\% DM).

\begin{tabular}{|c|c|c|c|c|c|c|}
\hline Parameters & Yield & Aw & $\mathrm{pH}$ & Dry matter (\%) & Ash (\%) & Protein (\%) \\
\hline $\begin{array}{l}\text { Agave americana } \\
\text { Inulin }\end{array}$ & $79.12 \pm 0.50$ & $0.275 \pm 0.013^{\mathrm{a}}$ & $5.53 \pm 0.55^{\mathrm{a}}$ & $92.19 \pm 0.28^{\mathrm{a}}$ & $2.89 \pm 0.31^{\mathrm{a}}$ & $3.46 \pm 0.13^{\mathrm{a}}$ \\
\hline Commercial inulin & $* * *$ & $0.282 \pm 0.011^{\mathrm{a}}$ & $5.98 \pm 0.34^{\mathrm{a}}$ & $91.67 \pm 0.76^{\mathrm{a}}$ & $1.19 \pm 0.18^{\mathrm{b}}$ & $1.58 \pm 0.11^{\mathrm{b}}$ \\
\hline
\end{tabular}

Means in the same column with different letters are significantly different $(P<0.05)$.

TABLE 3: Functional properties of Agave americana L. leaves powder, inulin extracted from Agaves americana, and commercial inulin obtained by lyophilisation.

\begin{tabular}{lccccc}
\hline Parameters & $\begin{array}{c}\text { Solubility at } 25^{\circ} \mathrm{C} \\
(\mathrm{g} / \mathrm{L})\end{array}$ & $\begin{array}{c}\text { WHC } \\
\text { (g of water/g of sample) }\end{array}$ & $\begin{array}{c}\text { OHC } \\
\text { (g of oil/g of sample) }\end{array}$ & $\begin{array}{c}\text { SP } \\
\text { (mL of water/g of } \\
\text { sample) }\end{array}$ & $\begin{array}{c}\text { Emulsion } \\
\text { capacity }(\%)\end{array}$ \\
\hline Agave powder & $* * *$ & $14.60 \pm 0.66^{\mathrm{c}}$ & $9.87 \pm 0.29^{\mathrm{b}}$ & $15.20 \pm 0.30^{\mathrm{b}}$ & $17.17 \pm 1.04^{\mathrm{c}}$ \\
$\begin{array}{l}\text { Agave inulin } \\
\text { Commercial }\end{array}$ & $73.47 \pm 0.14^{\mathrm{a}}$ & $2.42 \pm 0.18^{\mathrm{b}}$ & $3.26 \pm 0.59^{\mathrm{a}}$ & $1.99 \pm 0.13^{\mathrm{a}}$ & $14.48 \pm 0.23^{\mathrm{a}}$ \\
Inulin & $113.68 \pm 4.14^{\mathrm{b}}$ & $1.59 \pm 0.02^{\mathrm{a}}$ & $3.47 \pm 0.03^{\mathrm{a}}$ & $1.08 \pm 0.01^{\mathrm{a}}$ & $21.42 \pm 0.70^{\mathrm{b}}$ \\
\hline
\end{tabular}

Means in the same column with different letters are significantly different $(P<0.05)$.

WHC: water holding capacity, OHC: oil holding capacity, SP: swelling power.

AA) and calcium $(0.762 \mathrm{mg} / 100 \mathrm{~g}$ of AA) was observed and low levels of sodium $(0.092 \mathrm{mg} / 100 \mathrm{~g}$ of AA) and magnesium $(0.045 \mathrm{mg} / 100 \mathrm{~g}$ of AA) similarly net Aloe vera [46].

The $\mathrm{pH}$ of AA powder was 5.06 presented in Table 1. This value was higher than other fibre products such as pomegranate bagasses powder coproduct 4.4 [47] or orange dietary fibre 4.06 or lemon albedo $3.96[48,49]$.

Furthermore, Table 2 presents the physicochemical properties of inulin obtained from AA and inulin extracted from commercial chicory. Both inulins had a very high dry matter (91-92\%). Significant difference was observed between Agave inulin and commercial inulin $\mathrm{pH}$ (5.53 against 5.98, resp.) $(P<0.05)$. This result can be due to the differences between the two plant initial compositions.

The water activity of Agave inulin and commercial inulin $(P<0.05)$ was 0.275 and 0.282 , respectively. The water activity and $\mathrm{pH}$ of Agave inulin and commercial inulin, both parameters highly related to product deterioration, indicate that the risk of deterioration (by microorganism, enzymes, or no enzymatic reactions) is minimal.

Inulin from AA was characterized by a higher protein and ash contents than the commercial chicory inulin $(3.46 \%$ against $1.58 \%$ and $2.89 \%$ against $1.19 \%$, resp.). This significant difference can probably be due to the difference between the laboratory and the industrial purification process and the botanical differences between the two studied plants AA and chicory.

3.2. Functional Properties. Table 3 showed the functional properties of AA powder, Agave inulin, and commercial inulin. The WHC of Agave leaves powder had the highest level compared with Agave inulin and commercial inulin (14.60 g of water/g of sample against 1.59-2.42 g of water/g of sample). This result can be explained by the high Agave fibre content $(38.40 \%)$ and protein content $(35.33 \%)$ [50-53]. The obtained WHC of Agave leaves powder was higher than these of the fibroprotein extracts from date seeds ( $4-5 \mathrm{~g}$ of water/g of sample) [52], the citrus fiber (10.66 g of water/g of fiber) [42], grapefruit fiber (9.77 $\mathrm{g}$ of water/g of fiber) [50] and orange fiber (11 $\mathrm{g}$ of water/g of fiber) [54].

$\mathrm{OHC}$ of Agave leaves powder was $9.87 \mathrm{~g}$ of oil/g of the sample. Considering this value of oil retention, the Agave leaves powder could be employed as like ingredient to stabilize the products rich in oil. These WHC and OHC were a function of size, shape, hydrophilic, and hydrophobic interactions and were affected by the presence of carbohydrates, lipids, and amino acid residues on the surface, since most nonpolar amino acid residues and polar groups are not hydrated in the interior $[40,52]$. The particle size of Agave leaves powder and Agave inulin (particle size < $250 \mu \mathrm{m})$ affected technofunctional properties. Indeed, the very fine particles explained the importance of WHC and $\mathrm{OHC}$ increases. The high $\mathrm{WHC}$ and $\mathrm{OHC}$ of these Agave leaves powder and inulin suggest that it can be used as a functional ingredient to improve the sensory properties of the formulated product, to reduce syneresis, modify texture, viscosity, and reduce calories of foods.

The higher swelling property of Agave leaves powder might be attributed to its lower density and lager surface area among the fiber samples. Agave and commercial inulin have a lower swelling power than the Agave leaves powder (1$2 \mathrm{~mL} / \mathrm{g}$ against $15.20 \mathrm{~mL} / \mathrm{g}$, resp.). It was suggested that the differences in hydration properties were a function of the physical structure of the fiber, which could be manipulated by processing history. Experimental procedures, including how sample was prepared, alter the physical structure of the fiber, which could affect the hydration properties [55]. This could explain the differences in hydration properties observed between Agave leaves powder, Agave inulin, and commercial inulin. Hydration properties determine the role of dietary fiber in regulating colonic function and also their physiological effects $[56,57]$. 
TABLE 4: Effect of drying process on the technofunctional properties of inulin extracted from Agave americana leaves.

\begin{tabular}{|c|c|c|c|c|}
\hline Parameters & $\begin{array}{c}\text { WHC } \\
\text { (g of water/g of } \\
\text { sample) }\end{array}$ & $\begin{array}{c}\mathrm{OHC} \\
\text { (g of oil/g of sample) }\end{array}$ & $\begin{array}{c}\mathrm{SP} \\
\text { (mL of water/g of } \\
\text { sample) }\end{array}$ & $\begin{array}{c}\text { Emulsion capacity } \\
(\%)\end{array}$ \\
\hline Lyophilisation & $2.42 \pm 0.18^{\mathrm{a}}$ & $3.26 \pm 0.59^{\mathrm{a}}$ & $1.99 \pm 0.13^{\mathrm{a}}$ & $14.48 \pm 0.23^{\mathrm{a}}$ \\
\hline $\begin{array}{l}\text { Drying oven } \\
\left(T=40^{\circ} \mathrm{C}\right)\end{array}$ & $1.62 \pm 0.07^{\mathrm{b}}$ & $2.21 \pm 0.12^{\mathrm{b}}$ & $1.5 \pm 0.52^{\mathrm{a}}$ & $11.3 \pm 0.03^{b}$ \\
\hline $\begin{array}{l}\text { Drying oven } \\
\left(T=60^{\circ} \mathrm{C}\right)\end{array}$ & $1.36 \pm 0.01^{\mathrm{c}}$ & $1.90 \pm 0.04^{\mathrm{c}}$ & $1.15 \pm 0.68^{\mathrm{a}}$ & $10.49 \pm 0.66^{c}$ \\
\hline
\end{tabular}

Means in the same column with different letters are significantly different $(P<0.05)$.

WHC: water holding capacity, OHC: oil holding capacity, SP: swelling power.

The solubility of Agave inulin was significantly lower than those of commercial inulin $(73.47 \pm 0.14 \mathrm{~g} / \mathrm{L}$ against $113.68 \pm$ $4.14 \mathrm{~g} / \mathrm{L})(P<0.05)$. However, the solubility remained high for both. This high solubility in water probably affects the hydration properties of inulin.

The emulsion capacity (EC) is a molecule's ability to act as an agent that facilitates solubilization or the dispersion of two immiscible liquids. Emulsions are formed due to the presence of hydrophobic and hydrophilic groups of carbohydrate. The EC of the agave leaves powder was $17.17 \%$ and for Agave inulin was $14.48 \%$, while the EC of the commercial inulin was $21.42 \%$. Probably, a relationship was existed between emulsion properties and solubility of the studied fiber. This result suggests that the improvement of emulsification capacity could be due to the presence of soluble protein and fiber. M. Viuda-Martos et al. [47] reported similar result for pomegranate juice arils bagasse and pomegranate juice whole fruit bagasse.

3.3. Effect of Drying Process on the Technofunctional Properties of Inulin Extracted from AA Leaves. Table 4 presented the effect of varying the drying temperature on the technofunctional properties of the Agave inulin. If drying temperature increased, the various technofunctional properties decreased. For example, the WHC of lyophilized Agave inulin was higher than these obtained by drying oven Agave inulin. Therefore, it can be concluded that temperature of drying had an influence on the structure and hydrophobic characteristics of Agave inulin.

Significant difference was observed between the different drying processes (lyophilization, oven drying at $40^{\circ} \mathrm{C}$ and $60^{\circ} \mathrm{C}$ ) concerning the functional properties except swelling power. For example, the $\mathrm{OHC}$ decreased with the increase of drying temperature. The lyophilized inulin $\mathrm{OHC}$ was $3.26 \mathrm{~g}$ of oil/g of sample against $2.21 \mathrm{~g}$ of oil/g of sample for the oven dried inulin at $40^{\circ} \mathrm{C}$ and $1.90 \mathrm{~g}$ of oil $/ \mathrm{g}$ of sample for the oven dried inulin at $60^{\circ} \mathrm{C}$. Freeze-drying has provided the most appreciated technofunctional inulin. Certainly, this process preserved the inulin structure.

3.4. Synergetic Effect of Agave Inulin on Textural Qualities of Prepared Mixed Gels. The synergetic effect of prepared Agave leaves inulin-PHM mixed gel on texture parameters was studied and compared to PHM gel, commercial inulin gel, and the commercial inulin-pectin mixed gel. Figure 4 and Table 5

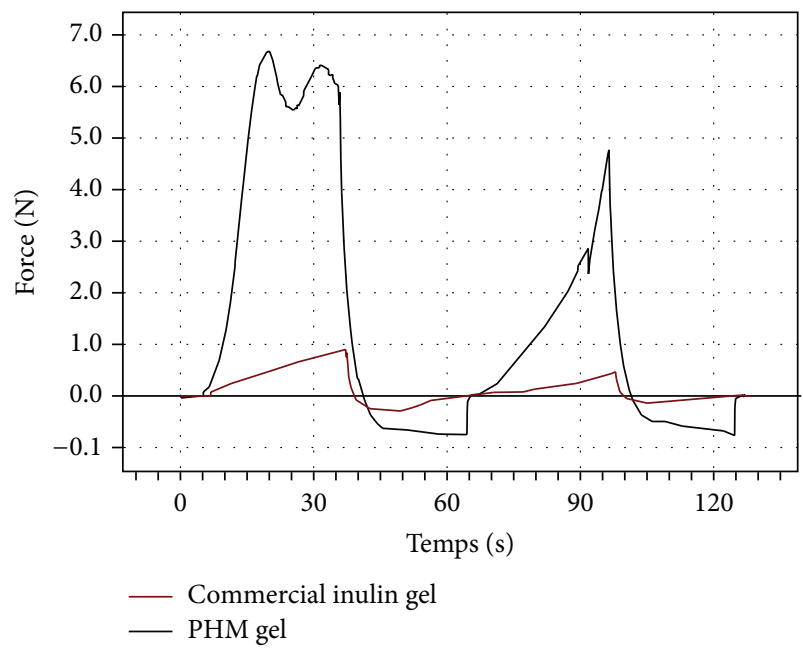

(a)

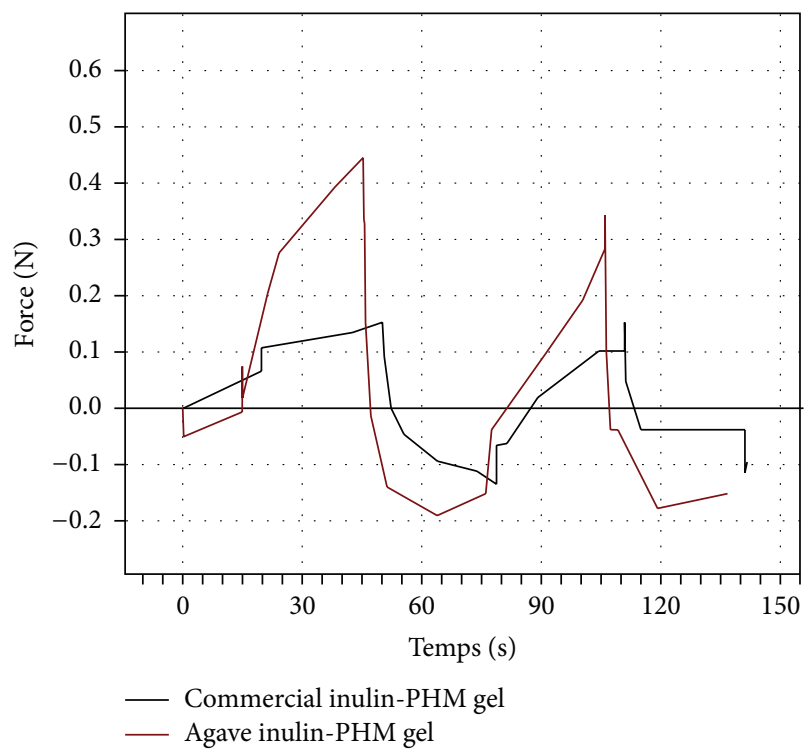

(b)

Figure 4: Texture profile of commercial inulin and PHM gels, commercial inulin-PHM, and Agave inulin-PHM gels.

exhibited the results of the textural analysis. The inulin showed a significant contribution to firmness, chewiness, 
TABLE 5: Texture parameters of different prepared gels with inulin and commercial high-methoxy pectin (PHM).

\begin{tabular}{|c|c|c|c|c|c|}
\hline Parameters & Firmness $(\mathrm{N})$ & Cohesiveness & Elasticity (mm) & $\begin{array}{l}\text { Chewiness } \\
(\mathrm{N} \cdot \mathrm{mm})\end{array}$ & $\begin{array}{l}\text { Adhesiveness } \\
(\mathrm{N} / \mathrm{mm})\end{array}$ \\
\hline Commercial Inulin & $0.6836 \pm 0.3068^{\mathrm{a}}$ & $0.3294 \pm 0.0236^{\mathrm{a}}$ & $14.7903 \pm 0.1655^{\mathrm{a}}$ & $4.1992 \pm 0.0013^{\mathrm{a}}$ & $1.2318 \pm 0.0583^{\mathrm{a}}$ \\
\hline Commercial PHM & $5.7238 \pm 1.3484^{\mathrm{b}}$ & $0.2762 \pm 0.0123^{\mathrm{a}}$ & $14.2419 \pm 0.1125^{\mathrm{a}}$ & $26.8461 \pm 0.1425^{\mathrm{b}}$ & $7.4136 \pm 0.0263^{b}$ \\
\hline $\begin{array}{l}\text { Commercial Inulin + } \\
\text { Commercial PHM }\end{array}$ & $0.1838 \pm 0.1440^{\mathrm{a}}$ & $0.4138 \pm 0.3784^{\mathrm{a}}$ & $9.2336 \pm 0.3594^{\mathrm{b}}$ & $1.0684 \pm 1.3346^{\mathrm{a}}$ & $0.9902 \pm 0.1792^{\mathrm{a}}$ \\
\hline $\begin{array}{l}\text { Commercial PHM + } \\
\text { Agave Inulin }\end{array}$ & $0.3554 \pm 0.0550^{\mathrm{a}}$ & $0.3149 \pm 0.0906^{\mathrm{a}}$ & $10.1741 \pm 1.0038^{\mathrm{b}}$ & $1.2663 \pm 0.3407^{\mathrm{a}}$ & $1.3051 \pm 0.1636^{\mathrm{a}}$ \\
\hline
\end{tabular}

Means in the same column with different letters are significantly different $(P<0.05)$.

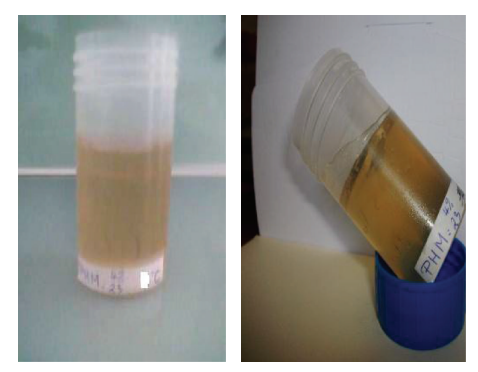

PHM gel

(a)

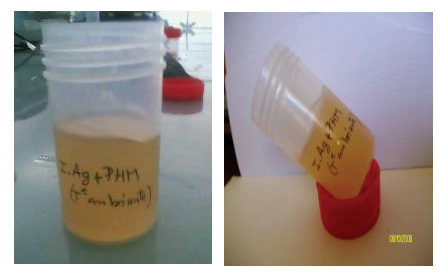

Agave inulin-PHM gel

(c)

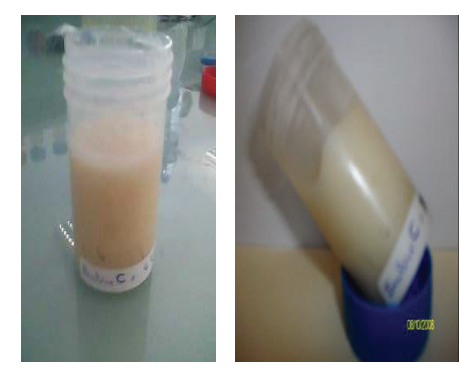

Commercial inulin gel

(b)

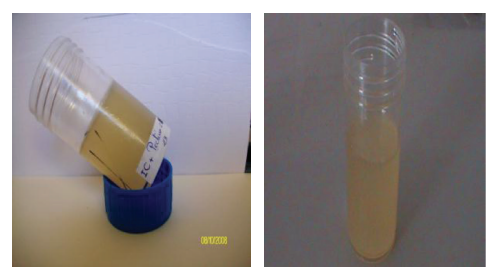

Commercial inulin-PHM gel

(d)

Figure 5: Different prepared gels in laboratory.

and adhesiveness of prepared inulin gels compared with commercial PHM gel.

The firmness is the force required to achieve a given deformation. No significant difference was observed between the firmness of the commercial inulin gel, the Agave inulinPHM and the commercial inulin-PHM mixed gels. Those prepared gels were very fragile and presented a significant different firmness compared to the commercial PHM gel $(P<$ 0.05). These low levels of firmness of the commercial inulin gel, the commercial inulin-PHM, and Agave inulin-PHM mixed gels could be explained by the presence of synergetic effect between inulin and PHM. For example, firmness of PHM-Agave inulin mixed gel is $0.3554 \mathrm{~N}$ against $5.7238 \mathrm{~N}$ for the PHM gel. However, firmness of PHM-Agave inulin mixed gel was slightly lower $(0.3554 \mathrm{~N})$ than these of commercial inulin gel $(0.6836 \mathrm{~N})$ and slightly higher than the commercial inulin-PHM mixed gel $(0.1838 \mathrm{~N})$. Probably, pectin reacts synergistically with Agave inulin which enhances the tenderness of mixed gels. This result can be explained by the presence of impurities from Agave inulin due to the absence of a purification step. Furthermore, firmness of the prepared gels decreased with the presence of inulin which confirms the synergy between these two hydrocolloids especially the inulin in improving the textural parameters of gels. These prepared gels were presented in Figure 5.

Adhesion was the maximum force required to remove the probe from the sample after applying a compressive force. According to the obtained results, no significant difference was shown between the adhesiveness of different prepared gels except those of PHM gel $(P<0.05)$. For example, adhesion of PHM-Agave inulin mixed gel was significantly lower than those of PHM gel $(1.3051 \mathrm{~N} / \mathrm{mm}$ against $7.4136 \mathrm{~N} / \mathrm{mm})$ $(P<0.05)$. These results confirmed the existence of synergy between principally inulin and PHM.

Cohesiveness was the ratio of the area under the curve of the second compression to the area under the curve of the first compression [58]. Table 5 indicates that the cohesion was very low in different gels. The cohesiveness levels, ranging between 0.2762 and 0.4138 , were not changing significantly for the mixed gels. 
Elasticity was the height at which the sample returns to its original size after compression [59]. Significant difference was shown between elasticity of commercial inulin and PHM gels and the mixed gels (Agave inulin-PHM and commercial inulin-PHM gels). However, the Agave inulinPHM or commercial inulin-PHM mixed gels were slightly lower compared with PHM and commercial inulin gels (9$10 \mathrm{~mm}$ against $14 \mathrm{~mm}$, resp.). These results can be explained by the synergetic effect between pectin and inulin gels.

Furthermore, these results could be explained in the fact that the Agave inulin contains proteins, sugars, and fibers other than inulin in low proportions. For example, the protein fraction present in the Agave inulin was about 3.46\%; thus more residues have probably a role in gelation such as the S-S bridge. They are involved in establishing a gel network. The Agave inulin-PHM gel had an appreciated texture more than the commercial inulin-PHM gel and gives importance to the Agave inulin to play the role of a texturing in various food formulations. Yet the saturation of synergy between inulin, protein, and pectin affected the general appearance of the mixed gels and revealed the higher affinity of compounds for the pectin matrix. Similar phenomena were reported between k-carrageenan and hydrocolloid from leaves of Corchorus olitorius [60].

Moreover, the presence of inulin can probably cause local disruptions of the pectin gel structure and at the same time reduces the freedom of polymeric chains of pectin for searching for an ordered binding. The Agave inulin changed the properties of the matrix resulting in a more nonpolar matrix. This is indicated by a larger retention of the more hydrophobic compounds than the less hydrophobic compounds in the more rigid gels [61].

When solutions of two biopolymers were mixed, interactions between their chains depend on the balance between the enthalpy and the entropy changes on mixing, being, therefore, either favorable (association) or unfavorable (segregation) [62]. Almost all biopolymer mixtures exhibit segregate interactions, unless there is an electrostatic drive to association. These usually result in phase separated networks where the components tend to exclude each other from their domains [63].

\section{Conclusion}

The present paper reported the basic chemical and physicochemical properties of inulin from leaves of AA obtained by water extraction. Results indicated the potentiality to valorize Agave americana L. leaves of Tunisia, especially inulin fraction. For gelling properties, it has revealed that PHM-Agave inulin gel exhibited lower firmness due to the synergy between Agave inulin and pectin in relation to gel strength. This synergy implies that inulin could not only be an alternative to pectin in many applications but may introduce new functions to inulin. Thus AA is an interesting source of inulin though further investigation should be done in order to fully explore the potential of this studied hydrocolloid.

\section{Conflict of Interests}

The authors declare that there is no conflict of interests regarding the publication of this paper.

\section{References}

[1] P. S. Nobel, Remarkable Agaves and Cacti, Oxford University Press, Oxford, UK, 1994.

[2] M. Irish and G. Irish, Agaves, Yuccas, and Related Plants: A Gardener's Guide, Timber Press, Portland, Ore, USA, 2000.

[3] M. D. García, A. M. Quílez, M. T. Sáenz, M. E. MartínezDomínguez, and R. de la Puerta, "Anti-inflammatory activity of Agave intermixta Trel. and Cissus sicyoides L., species used in the Caribbean traditional medicine," Journal of Ethnopharmacology, vol. 71, no. 3, pp. 395-400, 2000.

[4] A. T. Peana, M. D. L. Moretti, V. Manconi, G. Desole, and P. Pippia, "Anti-inflammatory activity of aqueous extracts and steroidal sapogenins of Agave americana," Planta Medica, vol. 63, no. 3, pp. 199-202, 1997.

[5] G. J. Uribe and S. S. Saldivar, "Agave syrup extracts having anticancer activity," US Patent AA61K31353FI, 2009.

[6] C. P. Khare, Indian Medicinal Plants: An Illustrated Dictionary, Springer Science and Business Media, 2007.

[7] P. E. Zwane, M. T. Masarirambi, N. T. Magagula, A. M. Dlamini, and E. Bhebhe, "Exploitation of AA L plant for food security in Swaziland," American Journal of Food and Nutrition, vol. 1, no. 2, pp. 82-88, 2011.

[8] B. Rodríguez-Garay, J. A. Lomelí-Sención, E. Tapia-Campos et al., "Morphological and molecular diversity of Agave tequilana Weber var. Azul and Agave angustifolia Haw. var. Lineño," Industrial Crops and Products, vol. 29, no. 1, pp. 220-228, 2009.

[9] G. Iniguez-Covarrubias, R. Díaz-Teres, R. Sanjuan-Duenas, J. Anzaldo-Hernández, and R. M. Rowell, "Utilization of byproducts from the tequila industry. Part 2: potential value of Agave tequilana Weber azul leaves," Bioresource Technology, vol. 77, no. 2, pp. 101-108, 2001.

[10] L. Guendo, Flore Europeenne, Hachette, Paris, France, 1998.

[11] A. Cuendo, G. Pottier-Alapetite, and A. Labbe, Flore analytique et synoptique de la Tunisie: Cryptogames vasculaires, Gymnospermes et Monocotylédones, Office de l'Experimentation et de la Vulgarisation Agricoles de Tunisie (SEFAN), Tunis, Tunisia, 1954.

[12] S. Msahli, J. Y. Drean, and F. Sakli, "Evaluating the fineness of Agave americana L. fibers," Textile Research Journal, vol. 75, no. 7, pp. 540-543, 2005.

[13] A. Bessadok, S. Marais, S. Roudesli, C. Lixon, and M. Métayer, "Influence of chemical modifications on water-sorption and mechanical properties of Agave fibres," Composites Part A, vol. 39, no. 1, pp. 29-45, 2008.

[14] J. Arrizon, S. Morel, A. Gschaedler, and P. Monsan, "Comparison of the water-soluble carbohydrate composition and fructan structures of Agave tequilana plants of different ages," Food Chemistry, vol. 122, no. 1, pp. 123-130, 2010.

[15] C. D. May, "Industrial pectins: sources, production and applications," Carbohydrate Polymers, vol. 12, no. 1, pp. 79-99, 1990.

[16] T. Ritsema and S. Smeekens, "Fructans: beneficial for plants and humans," Current Opinion in Plant Biology, vol. 6, no. 3, pp. 223230, 2003.

[17] J. van Loo, P. Coussement, L. de Leenheer, H. Hoebregs, and G. Smits, "On the presence of inulin and oligofructose as natural 
ingredients in the western diet," Critical Reviews in Food Science and Nutrition, vol. 35, no. 6, pp. 525-552, 1995.

[18] I. Austarheim, C. Nergard, R. Sanogo, D. Diallo, and B. Paulsen, "Inulin-rich fractionsfrom Vernonia kotschyana roots haveanti-ulceractivity," Journal of Ethnopharmacology, vol. 144, pp. 82-85, 2012.

[19] M. Roberfroid, "Dietary fiber, inulin, and oligofructose: a review comparing their physiological effects," Critical Reviews in Food Science and Nutrition, vol. 33, no. 2, pp. 103-148, 1993.

[20] D. Meyer, S. Bayarri, A. Tárrega, and E. Costell, "Inulin as texture modifier in dairy products," Food Hydrocolloids, vol. 25, no. 8, pp. 1881-1890, 2011.

[21] "Frutafit-inulin," in Handbook of Hydrocolloids, G. O. Phillips and P. A. Williams, Eds., pp. 397-403, Woodhead Publishing Ltd., Cambridge, UK, 2000.

[22] I. E. Bishay, "Rheological characterization of inulin," in Gums and Stabilisers for the Food Industry, P. A. Williams and G. O. Phillips, Eds., vol. 9, pp. 403-408, The Royal Society of Chemistry, London, UK, 1998.

[23] Y. Kim, M. N. Faqih, and S. S. Wang, "Factors affecting gel formation of inulin," Carbohydrate Polymers, vol. 46, no. 2, pp. 135-145, 2001.

[24] J. E. Zimeri and J. L. Kokini, "Rheological properties of inulinwaxy maize starch systems," Carbohydrate Polymers, vol. 52, no. 1, pp. 67-85, 2003.

[25] J. P. M. Van Duynhoven, A. S. Kulik, H. R. A. Jonker, and J. Haverkamp, "Solid-like components in carbohydrate gels probed by NMR spectroscopy," Carbohydrate Polymers, vol. 40, no. 3, pp. 211-219, 1999.

[26] P. Giannouli and E. R. Morris, "Cryogelation of xanthan," Food Hydrocolloids, vol. 17, no. 4, pp. 495-501, 2003.

[27] C. Löfgren, S. Guillotin, H. Evenbratt, H. Schols, and A. M. Hermansson, "Effects of calcium, $\mathrm{pH}$, and blockiness on kinetic rheological behavior and microstructure of HM pectin gels," Biomacromolecules, vol. 6, no. 2, pp. 646-652, 2005.

[28] C. Rolin and J. de Vries, "Pectin," in Food Gels, P. Harris, Ed., pp. 401-434, Elsevier, London, UK, 1990.

[29] J. F. Thibault and M. C. Ralet, "Physico-chemical properties of pectins in the cell walls and after extraction," in Advances in Pectin and Pectinase Research, F. Voragen, H. Schols, and R. Visser, Eds., pp. 91-105, Kluwer Academic Publishers, Dordrecht, The Netherlands, 2003.

[30] P. Walkenström, S. Kidman, A. M. Hermansson, P. B. Rasmussen, and L. Hoegh, "Microstructure and rheological behaviour of alginate/pectin mixed gels," Food Hydrocolloids, vol. 17, no. 5, pp. 593-603, 2003.

[31] V. Evageliou, R. K. Richardson, and E. R. Morris, "Co-gelation of high methoxy pectin with oxidized starch or potato maltodextrin," Carbohydrate Polymers, vol. 42, no. 3, pp. 233-243, 2000.

[32] I. M. Al-Ruqaie, S. Kasapis, R. K. Richardson, and G. Mitchell, "The glass transition zone in high solids pectin and gellan preparations," Polymer, vol. 38, no. 22, pp. 5685-5694, 1997.

[33] M. Masmoudi, S. Besbes, M. Chaabouni et al., "Optimization of pectin extraction from lemon by-product with acidified date juice using response surface methodology," Carbohydrate Polymers, vol. 74, no. 2, pp. 185-192, 2008.

[34] T. Paseephol, D. Small, and F. Sherkat, "Process optimisation for fractionating Jerusalem artichoke fructans with ethanol using response surface methodology," Food Chemistry, vol. 104, no. 1, pp. 73-80, 2007.
[35] AOAC, Official Methods of Analysis, Association of Official Analytical Chemists, Washington, DC, USA, 15th edition, 1995.

[36] S. Besbes, C. Blecker, C. Deroanne, G. Lognay, N. E. Drira, and H. Attia, "Quality characteristics and oxidative stability of date seed oil during storage," Food Science and Technology International, vol. 10, no. 5, pp. 333-338, 2004.

[37] L. Prosky, N. G. Asp, T. F. Schweizer, J. W. DeVries, and I. Furda, "Determination of insoluble, soluble, and total dietary fiber in foods and food products: interlaboratory study," Journal of the Association of Official Analytical Chemists, vol. 71, no. 5, pp. 1017-1023, 1988.

[38] R. Ninio, E. Lewinsohn, Y. Mizrahi, and Y. Sitrit, "Changes in sugars, acids, and volatiles during ripening of koubo (Cereus peruvianus (L.) Miller) fruits," Journal of Agricultural and Food Chemistry, vol. 51, no. 3, pp. 797-801, 2003.

[39] M. Dubois, K. A. Gilles, J. K. Hamilton, P. A. Rebers, and F. Smith, "Colorimetric method for determination of sugars and related substances," Analytical Chemistry, vol. 28, no. 3, pp. 350356, 1956.

[40] A. Moure, J. Sineiro, and H. Domínguez, "Extraction and functionality of membrane-concentrated protein from defatted Rosa rubiginosa seeds," Food Chemistry, vol. 74, no. 3, pp. 327339, 2001.

[41] C. Blecker, M. Paquot, I. Lamberti, A. Sensidoni, G. Lognay, and C. Deroanne, "Improved emulsifying and foaming of whey proteins after enzymic fat hydrolysis," Journal of Food Science, vol. 62, no. 1, pp. 48-74, 1997.

[42] J. A. Robertson, F. D. de Monredon, P. Dysseler, F. Guillon, R. Amadò, and J. F. Thibault, "Hydration properties of dietary fibre and resistant starch: a European collaborative study," Food Science and Technology, vol. 33, no. 2, pp. 72-79, 2000.

[43] S. N. Ronkart, C. Deroanne, M. Paquot, C. Fougnies, J. C. Lambrechts, and C. S. Blecker, "Characterization of the physical state of spray-dried inulin," Food Biophysics, vol. 2, no. 2-3, pp. 83-92, 2007.

[44] M. A. Ayadi, W. Abdelmaksoud, M. Ennouri, and H. Attia, "Cladodes from Opuntia ficus indica as a source of dietary fiber: effect on dough characteristics and cake making," Industrial Crops and Products, vol. 30, no. 1, pp. 40-47, 2009.

[45] Y. Chaabouni, J. Y. Drean, S. Msahli, and F. Sakli, "Morphological characterization of individual fiber of Agave americana L.," Textile Research Journal, vol. 76, no. 5, pp. 367-374, 2006.

[46] A. Femenia, A. C. Lefebvre, J. Y. Thebaudin, J. A. Robertson, and C. M. Bourgeois, "Physical and sensory properties of model foods supplemented with cauliflower fiber," Journal of Food Science, vol. 62, no. 4, pp. 635-639, 1997.

[47] M. Viuda-Martos, Y. Ruiz-Navajas, A. Martin-Sánchez et al., "Chemical, physico-chemical and functional properties of pomegranate (Punica granatum L.) bagasses powder coproduct," Journal of Food Engineering, vol. 110, pp. 220-224, 2012.

[48] Y. Lario, E. Sendra, C. García-Pérez et al., "Preparation of high dietary fiber powder from lemon juice by product," Innovative Food Science and Emerging Technologies, vol. 5, no. 1, pp. 113-117, 2004.

[49] M. C. Garau, S. Simal, C. Rosselló, and A. Femenia, "Effect of air-drying temperature on physico-chemical properties of dietary fibre and antioxidant capacity of orange (Citrus aurantium v. Canoneta) by-products," Food Chemistry, vol. 104, no. 3, pp. 1014-1024, 2007. 
[50] M. Fernandez, B. Borroto, J. A. Larrauri, and E. Sevillano, "Fibra dietetica de toronja: producto natural sin aditivos," Alimentaria, vol. 247, pp. 81-883, 1993.

[51] M. A. Bouaziz, W. B. Amara, H. Attia, C. Blecker, and S. Besbes, "Effect of the addition of defatted date seeds on wheat dough performance and bread quality," Journal of Texture Studies, vol. 41, no. 4, pp. 511-531, 2010.

[52] M. A. Bouaziz, S. Besbes, C. H. Blecker, and H. Attia, "Chemical composition and some functional properties of soluble fibroprotein extracts from Tunisian date palm seeds," African Journal of Biotechnology, vol. 12, no. 10, pp. 1121-1131, 2013.

[53] M. El-Gerssifi, "Les défauts des produits de pâtisserie et de biscuiteries au cours du stockage: la prévention par la formulation," Industries Alimentaires et Agriccoles, vol. 7, pp. 82-88, 1998.

[54] N. Grigelmo-Miguel, E. Carreras-Boladeras, and O. MartínBelloso, "Development of high-fruit-dietary-fibre muffins," European Food Research and Technology, vol. 210, no. 2, pp. 123$128,1999$.

[55] K. Zhu, S. Huang, W. Peng, H. Qian, and H. Zhou, "Effect of ultrafine grinding on hydration and antioxidant properties of wheat bran dietary fiber," Food Research International, vol. 43, no. 4, pp. 943-948, 2010.

[56] F. Guillon and M. M. J. Champ, "Carbohydrate fractions of legumes: uses in human nutrition and potential for health," British Journal of Nutrition, vol. 88, no. 3, pp. S293-S306, 2002.

[57] S. M. Tosh and S. Yada, "Dietary fibres in pulse seeds and fractions: characterization, functional attributes, and applications," Food Research International, vol. 43, no. 2, pp. 450-460, 2010.

[58] J. F. Meullenet, B. G. Lyon, J. A. Carpenter, and C. E. Lyon, "Relationship between sensory and instrumental texture profile attributes," Journal of Sensory Studies, vol. 13, no. 1, pp. 77-93, 1998.

[59] A. M. Munoz, "Development and application of texture reference scales," Journal of Sensory Studies, vol. 1, no. 1, pp. 55-83, 1986.

[60] E. Yamazaki, O. Kurita, and Y. Matsumura, "Hydrocolloid from leaves of Corchorus olitorius and its synergistic effect on $\kappa$ carrageenan gel strength," Food Hydrocolloids, vol. 22, no. 5, pp. 819-825, 2008.

[61] A. B. Boland, C. M. Delahunty, and S. M. Van Ruth, "Influence of the texture of gelatin gels and pectin gels on strawberry flavour release and perception," Food Chemistry, vol. 96, no. 3, pp. 452-460, 2006.

[62] L. Piculell, I. Iliopoulos, P. Linse et al., "Association and segregation in ternary polymer solutions and gels," in Gums and Stabilisers for the Food Industry, G. O. Phillips, P. A. Williams, and D. J. Wedlock, Eds., vol. 7, pp. 309-322, IRL Press, Oxford, UK, 1994.

[63] V. Evageliou, G. Tseliou, I. Mandala, and M. Komaitis, "Effect of inulin on texture and clarity of gellan gels," Journal of Food Engineering, vol. 101, no. 4, pp. 381-385, 2010. 

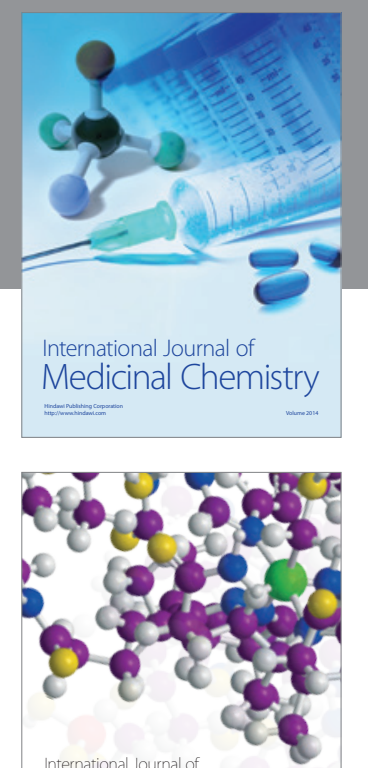

\section{Carbohydrate} Chemistry

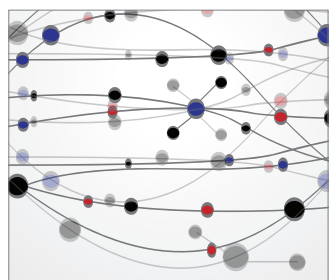

The Scientific World Journal
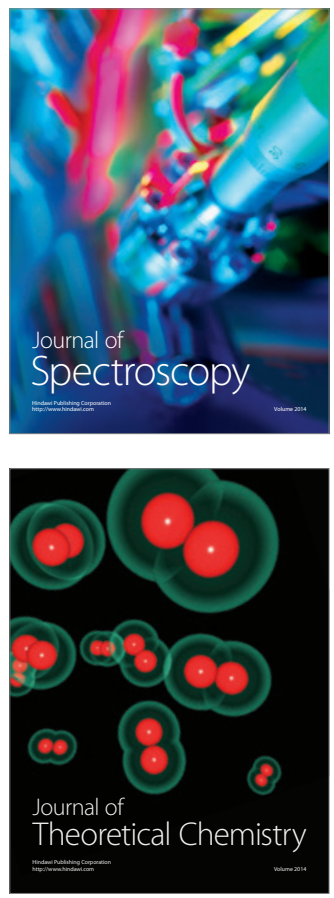
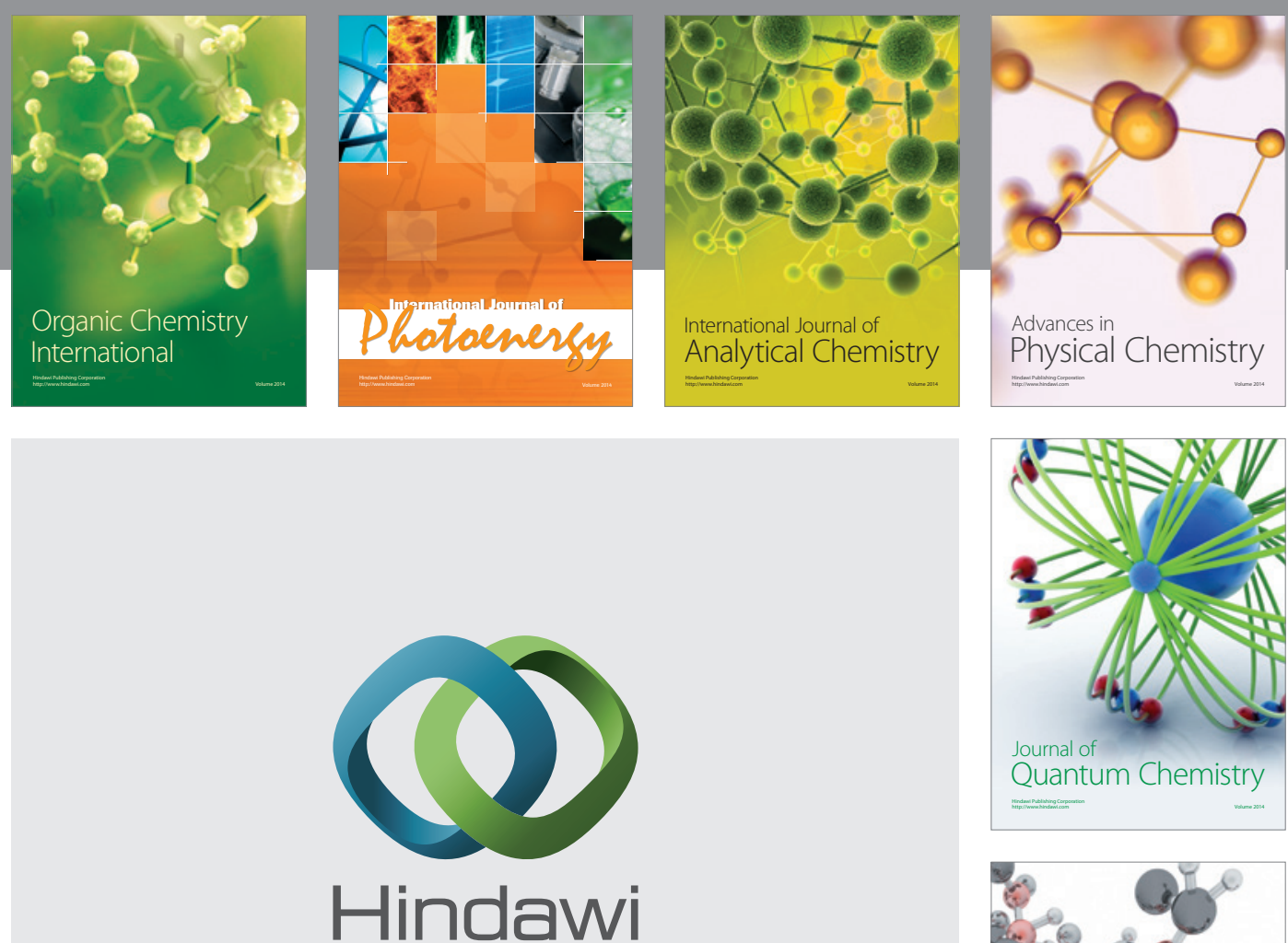

Submit your manuscripts at

http://www.hindawi.com

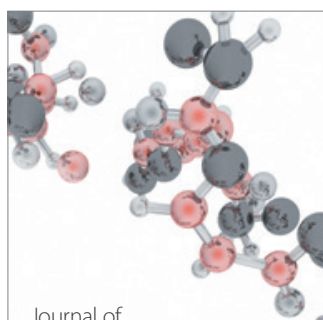

Analytical Methods

in Chemistry

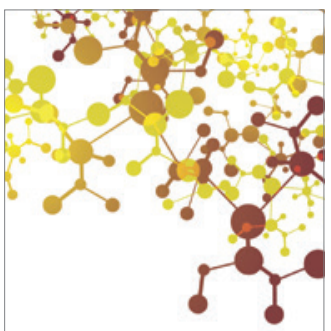

Journal of

Applied Chemistry

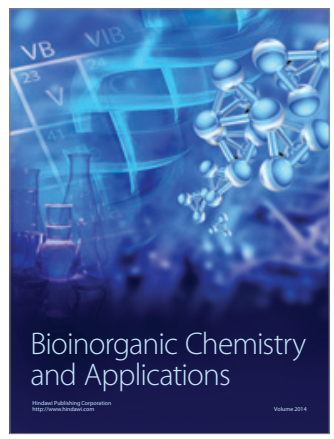

Inorganic Chemistry
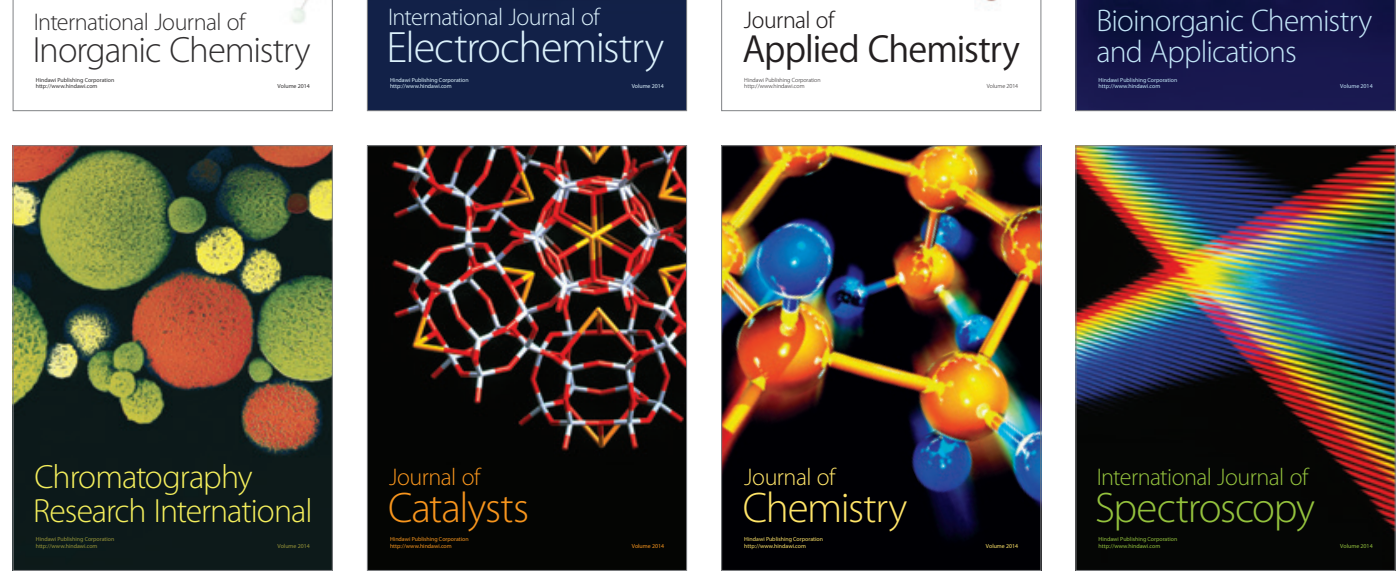